\title{
An Analysis of Students' Writing Past Conditional Sentence in Kabupaten Tangerang
}

\section{Cahya Adela ${ }^{1}$, Dwi Sloria Suharti ${ }^{2}$, Imtihan Hanim ${ }^{3}$}

${ }^{1}$ Sekolah Dasar Negeri Kedaung Wetan Baru 1

${ }^{2}$ English Education Study Program of Teacher Training and Education Faculty, Universitas Muhammadiyah Tangerang

${ }^{3}$ English Education Study Program of Teacher Training and Education Faculty, Universitas Muhammadiyah Tangerang

\section{ARTICLE INFO}

Keywords:

writing

grammar

past conditional sentence

\begin{abstract}
Writing English as a Foreign Language (EFL) requires one to applied writing rules such as language features: vocabulary, punctuation, type of text, text organization as well as appropriate Grammar, especially Past Conditional sentences. It is desired as a rule to convey one's expectations in their daily activities. The purpose of this research was to describe the difficulties and the factors that students of one of SMAN in Kabupaten Tangerang faced in writing using Past Conditional Sentence. The approach applied in this research was qualitative, and the method used in this research was descriptive analysis. Written tests and interviews were used to collect the data. The results of this research discovered the problems faced by students in writing using the Past Conditional Sentence. It was found that $73 \%$ of students had the same writing problem using past conditional sentences. The common mistakes were Verb and Auxiliary's wrong usage and incorrect application of Past Conditional formulas. Furthermore, it was revealed that the problems of language factors contribute to writing related to environmental, linguistics, and psychological factors.
\end{abstract}

This is an open access article distributed under the terms of the Creative Commons Attribution 4.0 International License, which permits unrestricted use, distribution, and reproduction in any 4.0 International License, which permits unrestricted use, distribution, and reproduction in any
medium, provided the original work is properly cited. (c) 2020 Cahya Adela, Dwi Sloria Suharti, Imtihan Hanim

\section{INTRODUCTION}

English as an International Language in the world, is learned by most people to communicate with each other. Learning English has become a great necessity for everyone who realized the importance of the language. English subject is focused on four skills. They are reading, speaking,

\footnotetext{
${ }^{1}$ Corresponding author's address: Sekolah Dasar Negeri Kedaung Wetan Baru 1, Tangerang, Banten, Indonesia e-mail: cahya.adela@gmail.com

2 Corresponding author's address: English Education Study Program of Teacher Training and Education Faculty, Universitas Muhammadiyah Tangerang, Banten, Indonesia e-mail: dwisloria@umt.ac.id

${ }^{3}$ Corresponding author's address: English Education Study Program of Teacher Training and Education Faculty, Universitas Muhammadiyah Tangerang, Banten, Indonesia

e-mail: imtihanhanim16@gmail.com
} 
listening, and writing. Writing is especially viewed to be complicated than the other skill because students should generate their idea into a paragraph to be good writing.

Many people cannot express something through conversation with each other. People should comprehend the conversation is to convey the message. As stated by Nikitina (2012, p.13), "Writing is not always an easy task, as a written message does not transmit vocal and non-verbal cues as spoken words do." It means that writing is one of the language skills that the student must master.

To have excellent writing, people need to learn Grammar. Grammar is one of the sub-skills which support in writing. As Scrivener (2003, p.252) stated, "'Learning grammar' has assumed a central role in students' expectations about what learning a language involves. Grammar refers to rules about sentence formation, tenses, and verb patterns. It involves some linguistic constituents ". It is a problem for students who study EFL. One of the many grammatical contents is conditional sentences.

In English, there are several types of Conditional Sentences. According to Alexander (2003, p.276), "Conditional sentences are usually divided into three basic types referred to as present conditional, past conditional, and future conditional." It refers to someone's daily activities to make a wish, dream, hope, and imagine what he or she wants to live. A past conditional sentence is like in Syllabus K13 English Specialization. Especially English Specialization at SMAN 5 Kabupaten Tangerang did the observation, which was in the syllabus as Past Conditional Sentence. The researchers interviewed the teacher and the students. There are several problems which are faced by the students in learning the material. First, the students lacked vocabulary. Second, they did not know the past conditional sentence. Third, It revealed that they had low motivation to study English. Besides, they had difficulty in interpreting the meaning of structure and function in past conditional sentences. Last, the teacher has been using a conventional method.

Based on those problems, this research is conducted to dig students' knowledge about the past conditional sentence. The researchers would like to conduct this research, which is entitled "An Analysis of Students' Writing Past Conditional Sentence in Kabupaten Tangerang". In this research, the researchers focused on the analysis of students' writing past conditional sentence at one of SMAN in Tangerang district. This study is addressed to know the students writing skill in the Past Conditional Sentence, and the researchers formulates the problems as follows :

1. Do the students encounter any difficulties in writing the past conditional sentence?

2. What factors do contribute to the lack of students' writing in the past conditional sentence?

The research was to know the students' difficulties of Past Conditional Sentence faced by the Social Eleventh grade at one of SMAN in Tangerang district.

\section{METHODOLOGY}

This research approach is a qualitative method. According to Creswell (2014, p.232), "Qualitative research, mentioning specific designs, carefully reflecting on the role the researchers plays in the study, drawing from an ever-expanding list of types of data sources, using specific protocols for recording data, analyzing the information through multiple steps of analysis, and mentioning approaches for documenting the accuracy or validity of the data collected." The researchers chose a qualitative approach because of present qualitative findings in the form of a narrative, descriptive, and discussed the fact is the result of the research.

The research is started by collecting data, both primary and secondary data using the students and written tests about past conditional sentences and interviewed the teacher at one of SMAN in Tangerang district. The research is started by collecting primary and secondary data. 


\section{FINDING AND DISCUSSION}

The researchers obtained the data from the school through gave interview 17 students and teacher and test, which got the result that was analyzed in this chapter. Also, the result of the test was about students' difficulties in Writing Past Conditional Sentence. The interview was about the factors that contribute to the lack of students' writing in the past conditional sentences.

1) Test

The researchers gave the test about Past Conditional Sentence to 34 students at one of SMAN in Tangerang district. The researchers gave the test about the past conditional sentence. It consists of 10 items to complete the sentence in fill in the blanks and ten items for the formation of the sentences. After conducting the test, the researchers analyzed the data to find students' difficulties in writing the past conditional sentence that the students made. The result of identifications can be seen as following in the table:

Table 4.1.The Incorrect Items of Students' Answer

\begin{tabular}{|c|c|c|}
\hline \multirow{2}{*}{$\begin{array}{l}\text { Name of } \\
\text { Students }\end{array}$} & \multicolumn{2}{|c|}{ Incorrect Items } \\
\hline & Fill in the Blanks & Changing the Sentences \\
\hline Student 1 & - & $1,2,3,5,10$ \\
\hline Student 2 & $1,3,5,6,7,9,10$ & $1,2,3,4,5,7,10$ \\
\hline Student 3 & $3,5,6,7,9,10$ & $1,2,3,5,10$ \\
\hline Student 4 & $3,5,6,7,9,10$ & $1,2,3,6,7,8,9,10$ \\
\hline Student 5 & $3,4,5,6,7,9,10$ & $1,2,3,5,6,8,10$ \\
\hline Student 6 & $3,5,6,7,9,10$ & $1,2,3,4,5,8,9,10$ \\
\hline Student 7 & $3,4,5,6,7,9,10$ & $1,2,3,4,6,8,9,10$ \\
\hline Student 8 & $3,5,6,7,9,10$ & $1,3,8,10$ \\
\hline Student 9 & $3,4,5,6,7,9,10$ & $1,2,3,7,8,9,10$ \\
\hline Student 10 & $3,6,7$ & $1,2,3,4,5,10$ \\
\hline Student 11 & $3,4,5,6,7,9,10$ & $1,2,3,4,5,7,8,10$ \\
\hline Student 12 & $3,4,5,6,7,9,10$ & $1,2,3,4,5,7,10$ \\
\hline Student 13 & $1,3,4,5,6,7,9,10$ & $1,2,3,5,6,8,9,10$ \\
\hline Student 14 & $3,4,5,6,7,9,10$ & $2,3,4,7,10$ \\
\hline Student 15 & $3,5,7,9$ & $1,2,3,4,5,6,8,9,10$ \\
\hline Student 16 & $3,4,5,6,7,9,10$ & $1,2,3,4,6,7,8,10$ \\
\hline Student 17 & 8,9 & $1,2,3,6,8,9,10$ \\
\hline Student 18 & $3,4,5,6,7,9,10$ & $1,2,3,4,5,8,10$ \\
\hline Student 19 & $3,4,5,6,7,9,10$ & $1,2,3,4,5,8,10$ \\
\hline Student 20 & $3,6,7,10$ & $1,2,3,4,5,8,9,10$ \\
\hline Student 21 & $3,4,5,6,7,9,10$ & $1,2,3,4,5,7,8,10$ \\
\hline Student 22 & - & $1,3,8,10$ \\
\hline Student 23 & $3,4,5,6,7,9,10$ & $1,2,3,5,10$ \\
\hline Student 24 & $1,3,4,5,6,7,9,10$ & $1,2,3,6,8,9,10$ \\
\hline Student 25 & $3,6,7,9$ & $1,2,3,4,5,8,10$ \\
\hline Student 26 & $3,5,6,7,10$ & $1,2,3,5,8,9,10$ \\
\hline Student 27 & $3,4,5,6,7,9,10$ & $1,2,3,4,5,7,8,10$ \\
\hline Student 28 & $3,4,5,6,7,9,10$ & $1,2,3,4,5,6,7,8,9,10$ \\
\hline Student 29 & 7,9 & $1,2,3,4,6,7,8,9,10$ \\
\hline Student 30 & $3,4,5,6,7,9,10$ & $1,2,3,5,7,8,10$ \\
\hline Student 31 & - & $1,3,6,8,10$ \\
\hline Student 32 & $3,4,5,6,7,9,10$ & $1,2,3,4,5,7,8,10$ \\
\hline Student 33 & $3,5,6,7,9,10$ & $1,3,4,8,10$ \\
\hline Student 34 & $3,4,5,6,7,9,10$ & $1,2,3,5,7,8,10$ \\
\hline
\end{tabular}


From the data of the table above, the researchers gave the test consisting of 34 students of Eleventh social grade at SMAN 5 Kabupaten Tangerang, and the researchers revealed that most students had many difficulties using past conditional sentence.

2) Interview

The researchers used the interview about the past conditional sentence to support the data. It took 17 students from 34 samples in class and one teacher. The interview was about the factors that contribute to the lack of students' writing in past conditional sentences: environmental, linguistic, and psychological factors.

\section{DISCUSSION}

In this research, the researchers gave an exercise about the past conditional sentence to students of at the Social Eleventh Grade at one of SMAN in Tangerang district as follows

\section{a. Student 1:}

Fill in the blanks:

It's too bad Helen isn't here. If she were here, she knew what to do

Fred failed the test because he didn't study. However, if he studied for the test, he passed it. If the weather were nice tomorrow, we went to the zoo.

I invited him to dinner with me. If he were my friend.

From the sentences above are incorrect. The students did not have knowledge about past conditional sentence. They could not change how to use past conditional sentence form instead of using auxiliary would in the sentence such as "would know" in past form. The correct sentence should be:

It's too bad Helen isn't here. If she were here, she would know what to do

Fred failed the test because he didn't study. However, if he studied for the test, he would pass it.

If the weather were nice tomorrow, we would go to the zoo.

I would invite him to dinner with me. If he were my friend.

\section{Transformation sentence as follow :}

If I had a spare ticket. I would take you to the concert.

He can type. He were able to operate computer.

From the sentences, it can be seen students lacks of auxiliaries from the question of the sentence is "can" and students answer past from can "would". The correct sentences :

If I had a spare ticket. I could take you to the concert.

He could type. He were able to operate computer.

Past form :

If she doesn't drink too much coffee, she would feel calm

If I doesn't fit, I wouldn't go climbing

From the sentences, it can be seen students lack of past conditional sentence. The students used doesn't or present tense. But, the form of past conditional sentence must use past tense and also must pay attention to use nominal or verbal past form. The correct sentence as follow :

If she didn't drink too much coffee, she would feel calm

If I were fit, I would go to climbing

\section{b. Student 2:}

Fill in the blanks:

If the teacher was absent tomorrow, class would be cancelled. 
You should tell your father exactly what happened. If I was you, I would tell him the truth as soon as possible.

From the sentences, it can be seen students lacks of be verb that wrong using "was" that must use "were", because in past conditional sentence all of subject must use "were" as be verb, the correct sentences as follow :

If the teacher were absent tomorrow, class would be cancelled.

You should tell your father exactly what happened. If I were you, I would tell him the truth as soon as possible.

\section{Transformation sentences as follow :}

If she doesn't drink too much. She would feel calm.

From the sentences, it can be seen students lacks of past form using "doesn' $t$ " in the sentence. It must "didn' $t$ ", because past conditional sentence used past tense the correct sentence :

If she didn't drink too much. She would feel calm.

If he can typed. He would be able to operate computer.

From the sentences, it can be seen students lacked of auxiliaries. After Auxiliary must use present and could to past form. The correct sentence as follow :

If he could type, He was able to operate computer

\section{c. Student 3:}

Fill in the blanks :

An aerosol spray can will explode if you throw it into a fire.

If the weather were nice tomorrow, we want to the zoo.

The sentences were incorrect, because the students lacked of verb "throw" and "want" that must change "would throw" and "would go". It means that past form of go was "went" not "want". Those were the correct sentences as follow :

An aerosol spray can will explode if you would threw it into a fire.

If the weather were nice tomorrow, we would go to the zoo.

\section{Transformation sentence as follow :}

If he didn't sats around too much. He would fit.

The sentence was incorrect. After past form must verb1 "didn't sit" not "didn't sats".

If he didn't sit around too much. He would fit.

If she was your position. She would able to advice you.

From the sentences, it can be seen students lacked of nominal past form used "was" in the sentence. It must "were", because past conditional sentence used past tense and all of the subject must use were. The correct sentence :

If she were your position, She would able to advice you

\section{d. Student 4 :}

Fill in the blanks :

You should tell your father exactly what happened. If I were you, I told him the truth as soon as possible.

From the sentences, it can be seen students lacked of past conditional sentence form. From the question of the sentence was "tell" and students answer past from can "told". It must use past conditional sentence added "would tell". The correct sentences as follow: 
You should tell your father exactly what happened. If I were you, I would tell him the truth as soon as possible.

\section{Transformation sentence as follow :}

If they understand the problem, they want find a solution.

From the sentences, it can be seen students lacked of past conditional sentence form and lacked of change the past of auxiliaries. From the question of the sentence need change to past form "Understood" and it was not want but rather "will". The correct sentences as follow :

If they understood the problem, They would find a solution.

\section{e. Student 5 :}

Fill in the blanks:

I got wet because I didn't take my umbrella. However. I wouldn't got we if I remembered to take my umbrella with me yesterday.

From the sentences, it can be seen the students lacked of auxiliaries. From the question of the sentence need change to past form "Wouldn't got" it must "Wouldn't get". The correct sentences as follow :

I got wet because I didn't take my umbrella. However. I wouldn't get we if I remembered to take my umbrella with me yesterday

\section{Transformation sentence as follow :}

If the weather sunny. We would stay indoors.

From the sentences, it can be seen the students lacked of tenses. From the question of the sentence needed to add to be "Wer" it must "Were sunny". The correct sentences as follow :

If the weather were sunny, We would stay indoors.

From the analysis of the data above, the researchers found many students got a low score in fill in the blanks and transformations sentence. Most of the students faced limitations of the vocabulary, lacked grammar structure, and a bit knowledge of how to arrange the sentence based on past conditional form.

Furthermore, from the incorrect sentences, the researchers did not explain all of the data that got by the test. It is only some of the data that the researchers analyzed because the students' difficulties were some of the other students, and the students made many difficulties in writing used past conditional sentences.

Additionally, the researchers mostly found the as same as data from students. The difficulties which students faced in the test included the students lacked vocabulary. The students lacked the past form, and they had less knowledge about the past conditional sentence. Based on the interviewed 17 students, the researchers found similar factors to Ellis (2009) that the students faced difficulties in learning grammar that three factors the difficulties related to environmental factors of language, with linguistic factors, and psychological factors in Effendi et al. (2017). Those were different factors which were the researchers revealed in this research, and three factors which consist of environmental, linguistic, and psychological factors.

Besides, the different of Ellis (2009) in Effendi et al. (2017) was linguistic factors which most of the students concerned in writing past conditional sentence. They had a limitation of vocabulary for English writing materials were not available. Finally, the students only knew a few vocabularies that they often used in learning the Past Conditional Sentence. Besides, the students had low knowledge in irregular and regular verbs, so they could not change the verb in the Past Conditional Sentence form to use past form. Consequently, the difficulties of using Grammar, which was better in English it focused on an environment where Indonesian used English as a 
foreign language. They also learned English at school as one of the subjects, and it was not interested in students who make them lazy and bored in the classroom. It was the reason they did not know linguistics in learning English due to lack of knowledge, lack of use of English, and motivation to learn English well.

Furthermore, psychological things that build mentally to want to learn English could affect their language skills, because it made students were lazy to learn English. Learning English looked difficult because the students had to memorize and practiced it so that students should master the language well. Confidently, intense effort and self-ability must be encouraged in this matter.

Furthermore, the researchers took two journal from Ellis (2009) in Effendi et al. (2017) mentioned about the factors that contribute in students' difficulties in learning grammar which consist of environmental, linguistic, and psychological factors and Normazida et al (2012) in Vongsa et al (2013) that mentioned about students' difficulties in learning grammar which consist of English was regarded as a difficult subject to learn, learners' learning depends on the English teachers as authorities in the classroom, the students' lack of support to use English in the home environment and the community, the students had insufficient or lacked of exposure to the language as there was a limited opportunity to use English outside the classroom, the students had a limitation of vocabulary proficiency as well as English writing materials were not available, the students had an unwillingness and lack of motivation to learn English as they did not see the immediate need to use the language, the students lack of motivation for learning or the negative attitude towards to the target language. As a result, the researchers compared these journals that similar to the result of the interview. They did not discuss the linguistic factors. The students had a limitation of vocabulary for English writing materials were not available. They only knew a few vocabularies that they often used in learning past conditional sentences, and the students had low knowledge of irregular and regular verbs.

\section{CONCLUSION}

The researchers concluded that based on the analysis of students' writing past conditional sentence of the eleventh social grade at one of SMAN in Tangerang district. The written test data found that most of the students were still tricky in writing past conditional sentences. They lacked knowledge about past conditional sentence form as they did not understand the form of past conditional sentences. They lacked the vocabulary, especially in irregular verbs, because they did not know how to change present to past form. From the interview, it was revealed that dominant factors were contributed to writing past conditional sentences. The factors were environmental, linguistic, and psychological factors of the language. Environmental factors occurred to the students who were their learning depended on their English teacher in the classroom, especially Past Conditional Sentence. The teacher still used the conventional method. Also, there was lacked support to use English at home environment and the community in the daily activities to the students who were lazy and shy to use English. Linguistic factors: the students had limited vocabulary and had less knowledge of irregular and regular verbs, so they could not change the verb in the Past Conditional Sentence form, which was to use past form. In psychological factors, the students who learned English regarded as a difficult subject to learn. Besides, they considered English as an unimportant language. There was a negative attitude towards the target language for the students who were learning English, and the people around them did not support the students in learning English.

\section{REFERENCES}

Abbas, A M. (2012), No 5. Conditional Sentences in English and Kurdish : A Contrastive Study. College of Basic Education/University of Sulaimini.

Alexander, L G. (2003). English Grammar. Edinburgh Gate, Harlow: Longman. 
Alfaki, I.M. (2015), Vol. 3 No.3. University Students' English Writing Problems: Diagnosis and Remedy. Sudan: Europan Center for Research Training and Development UK.

Alhaisoni, E. (2017) Vol.8 No.1. EFL Teachers' and Learners' Perceptions of Grammatical Difficulties. Saudi Arabia: Advances in Language and Literary Studies.

Al Rdaat, S H. (2017) Vol. 8 No. 2. An Analysis of Use of Conditional Sentences by Arab Students of English. United Kingdom: Coventry University

Bloor, T and Bloor, M (2013). The Functional Analysis of English. USA and Canada: Routledge.

Brown, H.D \& Abeywickrama, P (2010). Language Assessment Principles and Classroom Practices Second Edition. New York: Pearson Education.

Brown, H.D (2000). Teaching by Principles an Interactive Approach to Language Pedagogy Second Edition. San Fransisco, California: Pearson Education.

Creswell, J W. (2014). Qualitative, Quantitative, and Mixed Methods Approaches Research Design. California: Teller Road.

Droga, L \& Humphrey, S. (2005). Grammar and Meaning (An Introduction for Primary Teachers. Australia: Target Texts.

Efendi, M.S.et al . (2017) Volume 5. A Study on Grammar Teaching at an English Education Department in an EFL Context. English Education Program: Universitas Ahmad Dahlan.

Effendi, MS, et al. (2017) Volume.5. A Study in Grammar Teaching at an English Education Department in an EFL Context. Universitas Ahmad Dahlan: International Journal on Studies in English Language and Literature (IJSELL).

Fernald, G.f (Revised By Galc, C). (1979). English Grammar Simplified. New York, Hagerstown, San Francisco, London: First Barnes \&Noble Books.

Foley, M \& Hall, D. (2004). Advanced learners' Grammar. China: Longman.

Graus, J, \& Arno, P (2015). Defining Grammar Difficulty: A Student Teacher Perspective. Netherlands: HAN University of Applied Sciences.

Haynes, J \& Zacarian, D. (2010). Teaching English Language Learners Across the Content Areas. USA: ASDC.

Husin, M S and Nurbayani, E. (2017) Vol. 17 No.2. The Ability of Indonesian EFL Learners in Writing Academic Papers. State Institute of Islamic Studies of Samarinda, Indonesia.

Maurer, J. (2006). Focus on Grammar an Integrated Skills Approach Third Edition. New York: Pearson Education.

Muslim, I M. (2014) Vol. 4 No. 2. Helping EFL Students Improve their Writing. English Department College of Education for Women Baghdad University

Nikitina, A. (2012). Improve Your Writing Skills. Ventus Publishing APS (Bookboon.com).

Scrivener, J. (2005). Learning Teaching A Guide Book for English Language Teachers Second Edition. UK: A Division of Macmillan Publisher of Limited.

Souriyavongsa, T \& Rany, S et al. (2013) Vol. 1 No. 1. Factors Causes Students Low English A Case Study in the National University of Laos. Malaysia: School of Educational Studies, Universiti Sains Malaysia. 